\title{
Analysis of Authorized Economic Operator Policy in the Tanjung Priok Customs and Excise Service Office: Strengths and Weaknesses
}

\author{
Berlian Kusuma Bachtiar ${ }^{1, *}$ Inayati $^{2}$
}

\author{
${ }^{1}$ Department of Fiscal Administration, Universitas Indonesia \\ 2 Department of Fiscal Administration, Universitas Indonesia \\ *Corresponding author. Email: berliankusuma89@gmail.com
}

\begin{abstract}
Export/import activities are the main activities in international trade. In order to carry out these activities, a policy supporting the ease and resolution of customs issues in managing import and export is needed. One of the implemented policies is an Authorized Economic Operator policy (AEO policy). The aim of this study is to analyze the strengths and weaknesses of the implementation of the regulation PMK227/PMK.04/2014 concerning certified economic operators, in resolving customs issues. This research used a qualitative approach with in-depth interviews. The results show that this policy has an advantage in accelerating customs administration. A disadvantage of the policy is a high compliance cost for a taxpayer to fulfill the requirements. There are several problems while implementing this policy. First, the service business actors cannot get the benefits of the AEO policy. Second, there are some issues regarding human resources and the Information Technology system. Third, the lack of coordination among the institutions related to customs processes.
\end{abstract}

Keywords: Strengths, Weaknesses, Policy Implementation, Authorized Economic Operator

\section{INTRODUCTION}

International trade is aimed at meeting the needs among countries and seeking profits in trade. Over time, the need for goods and services in a country, especially Indonesia, continues to increase. This has led to several export/import issues that must be faced, including security issues of goods supply, complicated administration, and long dwell time. These three issues are quite familiar things in the customs world, including Indonesia Customs. These problems greatly hamper the process of managing exports and imports, which can hinder the process of distribution of goods and increase the cost of goods distribution.

To overcome these problems, the World Customs Organization (WCO) made a certification concept called Authorized Economic Operator (AEO). According to the SAFE Framework of WCO standards, the AEO is an economic operator involved in the movement of goods in the supply chain internationally, in any function that has been recognized by the national Customs administration, because it meets the WCO standards or the supply chain security standards (Bea cukai, 2015). Economic operators who can join the AEO program include: producers, importers, exporters, PPJK, freight forwarders, consolidators, intermediaries, port authorities, terminal managers, warehousing entrepreneurs, and distributors.

The Directorate General of Customs and Excise (DJBC), as the main institution in the implementation of exports and imports, has a role of the leader in developing this AEO program. In addition, DJBC has the authority to coordinate with other agencies and become the only institution entitled to grant AEO certificates to the Customs administrations. The implementation of Customs facilitations, specifically the AEO is not new in Indonesia. Indonesia has already implemented the Customs MITA facilitations. The provision of AEO certification itself is based on certain criteria listed in PMK 227 / PMK.04 / 2014. The benefits, listed in PMK 227/PMK.04/2014, aim to provide stable and significant support in creating a more conducive business climate. Those benefits include accelerating Customs administration, ease of loading and 
unloading, and other benefits. These benefits are expected to reduce the logistical costs incurred by businessmen and reduce dwell time. To sum up, it can create a good business climate, increase domestic investment, and open the possibility of increasing the State Tax Revenues.

In fact, this policy is very beneficial to businessmen who have obtained the AEO and DJBC certificates. However, the problems such as complicated Customs administration, unreduced dwell time, and lack of security in the distribution of goods, have not been resolved properly. The research questions of this study are:

1. What is the analysis of strengths and weaknesses in the utilization of AEO?

2. How does the implementation of the AEO policy facilitate customs administration acceleration?

\section{LITERATURE REVIEW}

\subsection{Policy implementation}

Pressman and Wildavasky in Signé (2017) formulated one of the initial definitions of implementation as 'the ability to forge subsequent links in the causal chain, so as to obtain the desired results'. Implementation is considered as a process, output or outcome, and involves several actors, organizations, and techniques for control.

George Edward III (Winarno, 2002) argues that implementation is crucial for public administration and public policy. Implementation is the policy stage between the formation of programs and the policy consequences for the people it influences. In reviewing the implementation of public policy, Edward III began by asking two questions, namely (i) what factors support the successful implementation of the policy? And (ii) what factors hinder the successful implementation of the policy? Edward III answers these questions by examining four factors of policy, i.e. communication, resources, disposition, and bureaucratic structure.

\subsection{Ease of administration concept}

In collecting taxes, there are principles or principles that must be considered in the tax collection system. According to Adam Smith (Haula \& Irianto 2014, p. 157), tax collection should be based on four principles, i.e. equity, certainty, convenience, and economy. These principles are more often referred to as the four maxims of Adam Smith. Haula Rosdiana and Edi Slamet Irianto (2014, p. 158) mention in their book, among other principles, the principles of taxation, revenue productivity, equity/equality, and ease of administration which were pursued by 1984 tax reform. The ease of administration is a principle that is more focused on the ease of tax administration. According to this principle, there are four concepts that must be considered, namely, certainty (legal certainty), efficiency (taxpayers compliance costs and administrative costs for low-tax authorities), convenience of payment (taxes being collected at a convenient time), and simplicity.

In determining costs, researchers use compliance cost indicators that consist of Direct Money Cost, Time Cost, and Psychological Cost. Compliance costs (compliance costs) are not always costs that can be measured (tangible) by money, but also costs that cannot be measured (intangible) by money. In terms of taxpayers, compliance costs incurred by taxpayers in order to meet their tax obligations fall into three groups, as follows (Rosdiana \& Tarigan 2005, p. 136):

1. Direct Money Cost, i.e., costs that can be measured in terms of money that taxpayers incur relating to the process of implementing tax obligations and rights, such as employee's wages/salaries, consulting services, transportation costs, and the cost of printing tax forms.

2. Time Cost, i.e., the cost of the time needed to carry out tax obligations and rights, such as time to fill in tax forms, time to submit tax returns, time needed to discuss taxation issues with consultants, time needed to discuss the final inspection report, and time required for an appeal.

3. Psychological Cost, i.e., incurred psychological costs, such as stress or unrest, anxiety, and uncertainty that occur in the process of implementing tax obligations and rights. Calculation of the psychological costs is a quite difficult component; this is because psychological costs are not like other costs that have parameters which are easier to establish.

\subsection{Authorized Economic Operator concept}

According to the $\mathrm{WCO}$, as outlined in the $\mathrm{WCO}$ SAFE Framework of Standards, Certified economic operators or AEO are economic operators involved in the movement of goods in the supply chain internationally, in any function that has received recognition by the national Customs administration because it meets WCO standards, including economic operators that can join the AEO, such as producers, importers, exporters, PPJK (Customs services company), freight forwarders, consolidators, intermediaries, port authorities, terminal managers, warehousing entrepreneurs, and distributors (Bea Cukai 2015). If a company has been recognized as an AEO, it means the company can prove the reliability and security of its customs. In addition, it means that the company gets access to streamline its customs 
procedures (Erceg 2014).

\section{METHODOLOGY}

This study uses qualitative, descriptive methods (Neuman 2006, p. 13). To get the primary data in this study, it is necessary to conduct field studies through indepth interviews with stakeholders among other DJBC and BKF officers, tax consultants, and customs agents who have obtained the AEO certificates. Qualitative data analysis used by researchers is an Ideal Type data analysis, which is done by comparing social reality with an ideal condition or type (Neuman 2006, p. 467).

\subsection{Strengths of Authorized Economic Operator policy}

\subsubsection{Acceleration of customs administration}

According to the regulation PMK227/PMK.04/2014 concerning Authorized economic operators, as per Article 3 , paragraph 2, businessmen who have AEO certificates are granted the benefit of accelerating Customs administration. The AEOs policy must suppress Customs problems, one of which is a complicated Customs administration. By being given the benefits of minimum document/physical check and the priority of obtaining simplification of Customs procedures, Customs administration should be easier and faster. The time taken for businesses that have the AEO certificates is less than one day. This is because Customs compliance processes are accelerated or skipped, for example there are the benefits of pre-notification and truck loosing.

Indonesia has three customs channels, i.e., red, yellow, and green channel. In the red channel, businessmen will undergo a thorough physical and document examination, the yellow channel is only a document check, and in the green channel there is less inspection than in the red and yellow channels. These three channels determine when goods can exit the boundary area. In order to show the difference in time consumed by each channel, the following 5.1 table displays the Customs channels and the AEO:

Table 5.1. Customs channels and AEO

\begin{tabular}{|l|l|l|}
\hline Channel & Activity & Time Consumed \\
\hline Red & $\begin{array}{l}\text { Document and } \\
\text { Physical Check }\end{array}$ & 3-5 days \\
\hline Yellow & Document Check & 2-3 days \\
\hline Green & $\begin{array}{l}\text { Selective Check (if } \\
\text { available) }\end{array}$ & Max 1 day \\
\hline AEO & - & Max 1 day \\
\hline
\end{tabular}

Source: Author's own data, 2019
The implementation of the provision of benefits, specifically for the Customs administration acceleration, was carried out quite well, and was even confirmed by a note, if the administration takes more than one day, it would make the distribution process run more smoothly in accordance with the objectives of AEO policy.

In addition to accelerating the Customs procedures, this AEO policy can save distribution costs. This is because the AEO policy can issue goods within a maximum of one day, thus saving distribution costs. The following table 5.2 lists the domestic container costs:

Table 5.2. List of domestic container fees

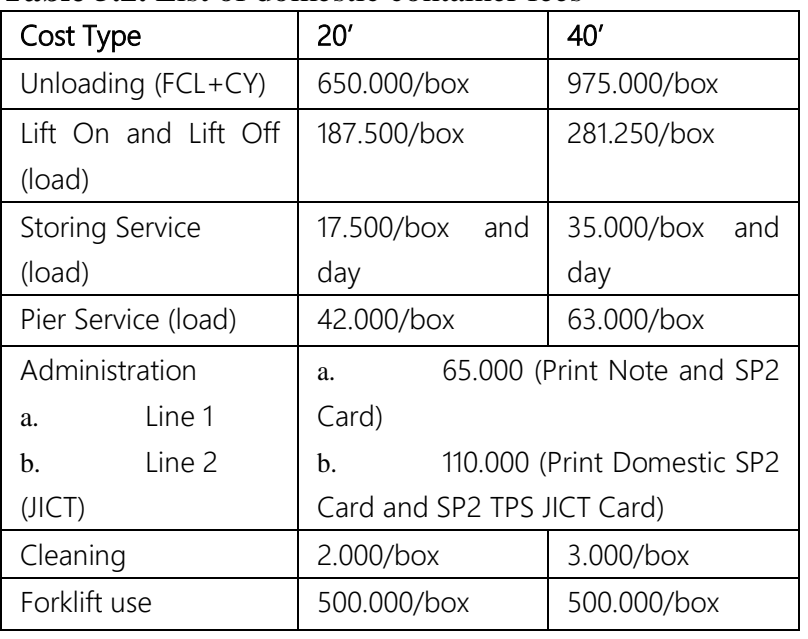

Source: IPC Pelindo II PETIKEMAS

As seen from the table 5.2, a lot of costs must be incurred by businessmen, especially exporters/importers if they enter the red or yellow channel which include physical check or documents check. Seven costs must be incurred by the businessmen if they enter a red, yellow, or selective channel. In order to show the difference more clearly among the red, yellow, green, and AEO channel, the following table 5.3 contains the differences in the pathways including the conditions, as follows:

- Red channel: 10 Container Imports (20 '), 5 days' inspection

- Yellow channel: Import 10 Container (20 '), 2 days' inspection

- Green channel: 10 Container Imports (20 '), without inspection (facilitations)

- AEO channel: Import 10 Container (20 '), without inspection (benefit) 
Table 5.3. Difference in cost, time of exit and the AEO

\begin{tabular}{|l|l|l|l|l|}
\hline Cost & Red & Yellow & Green & AEO \\
\hline $\begin{array}{l}\text { Checking } \\
\text { time }\end{array}$ & 5 days & 2 days & - & - \\
\hline $\begin{array}{l}\text { Unloading } \\
\text { and loading }\end{array}$ & 6.500 .000 & 6.500 .000 & 6.500 .000 & 6.500 .000 \\
\hline Lift on/off & 1.875 .000 & 1.875 .000 & 1.875 .000 & 1.875 .000 \\
\hline $\begin{array}{l}\text { Storing } \\
\text { Service }\end{array}$ & 875.000 & 350.000 & - & - \\
\hline Pier Service & 420.000 & 420.000 & 420.000 & 420.000 \\
\hline $\begin{array}{l}\text { Administra- } \\
\text { tion }\end{array}$ & 175.000 & 175.000 & 175.000 & 175.000 \\
\hline Cost & Red & Yellow & Green & AEO \\
\hline Cleaning & 20.000 & 20.000 & - & - \\
\hline Forklift use & 5.000 .000 & 5.000 .000 & - & - \\
\hline Total & 14.865 .000 & 14.340 .000 & 8.970 .000 & 8.970 .000 \\
\hline
\end{tabular}

Judging from the table 5.3, businessmen, especially importers who enter the red and yellow channel, have to pay higher costs than businessmen who enter the green channel or those who have obtained AEO certificates. A striking difference is in the dwell time and incurred costs. The maximum dwell time required for Customs clearance is only one (1) day. As for fees, the AEO can save around Rp.5,000,000-5,800,000. For this reason, the benefits of the Customs administration statement from the AEO policy prove to be more effective and efficient than other facilitations.

\subsubsection{Ease of loading and unloading}

In the concept of AEO, this policy has a goal, one of which is the simplification of customs procedures. The ease of the loading and unloading process is a result of an accelerated customs administration process (see table 5.1) The following table 5.4 is about saving the time for Customs administration and the AEO loading and unloading compared to other Customs channels:

Table 5.4. Time savings with other Customs channels

\begin{tabular}{|l|l|l|}
\hline Channel & $\begin{array}{l}\text { Loading and Unloading } \\
\text { Customs Administration } \\
\text { Time }\end{array}$ & Savings \\
\hline Red & $3-5$ days & $2-4$ days \\
\hline Yellow & $2-3$ days & $1-2$ days \\
\hline Green & 1 days & - \\
\hline AEO & Max 1 day & - \\
\hline
\end{tabular}

Source: Author's own data, 2019
As seen from table 5.4, the savings from AEO policy are quite good; the striking difference is between the AEO and the red channel, which could save two-four days. In terms of Customs administration and loading and unloading, this policy is superior to other channels. This is also in accordance with one of the AEO principles, i.e., the simplification of Customs administration.

\subsubsection{Security in the customs process}

According to Authorized Economic Operators policy, businessmen who have AEO certificates are given special service benefits in the event of disruption to the movement of logistics supplies and increasing threats. As per PMK 227/ PMK.04/2014, Article 2 stipulates 13 requirements for fulfilling the AEO certification. Items 6-11 or 50\% of the requirements that must be met are security items, starting from access, cargo security, goods movement security, location security, employees' security, all the way to the security of trading partners. In fact, the six items will be validated by DJBC in accordance with the standards that must be met, namely, the AEO standard.

By its implementation, businessmen, especially exporters or importers or goods storing services, must have warehouses, places, or facilities that are in accordance with the AEO standards thus fulfilling the security requirements. In addition, the access to these places or facilities must be strict and using protection such as fingerprint access control.

In the author's opinion, this policy strongly upholds security in the customs process. The intention is to make the supply chain of goods safe in accordance with the AEO principles, namely, safety and security. In addition, DJBC provides assistance related to Information Technology (IT) security system. DJBC as a facilitator guarantees that existing IT systems are safe, and if there are problems related to Customs, they can be resolved properly and quickly.

\subsubsection{Special priority/service programs and other benefits}

There are other advantages for the businesses if they have AEO certification, such as the use of a corporate guarantee. A corporate guarantee is a written guarantee by which the company guarantees that all customs activities are carried out by the company, and that the customer may make periodic payments. In practice, before having the AEO certificate, companies usually have to pay customs bonds of $1.5 \%-2 \%$ (of the import value) to the bank. So, the benefits of corporate guarantees and periodic payments are enough to help cash flow of businesses having the AEO certification. 
In addition to the above-mentioned advantages, another advantage of this policy is the existence of a Mutual Recognition Agreement. Mutual Recognition Agreement is a bilateral agreement between two (2) countries regarding the implementation of AEO, with the benefits of the AEO in a country recognized in the other country, so that the customs process is accelerated in both countries.

\subsection{Weaknesses of certified economic operator policy}

\subsubsection{Required costs during the implementation of AEO policy}

In fulfilling the requirements stipulated in PMK 227/ PMK.04/2014, incurring costs by businesses are required. These costs can be in the form of infrastructure costs to fulfill the requirements, costs of employees' salaries, training/seminar fees, and fees for customs and excise consultants (see table 5.5).

Table 5.5. Types and amounts of costs related to the implementation of the AEO

\begin{tabular}{|c|c|c|}
\hline Cost Type & Amount & $\begin{array}{l}\text { Routine/Only } \\
\text { Once }\end{array}$ \\
\hline $\begin{array}{l}\text { Salaries/Wages } \\
\text { (Customs } \\
\text { Experts) }\end{array}$ & $\begin{array}{l}5.000 .000- \\
10.000 .000 / \\
\text { month* }\end{array}$ & $\begin{array}{l}\text { Per month } \\
\text { (Routine) }\end{array}$ \\
\hline $\begin{array}{l}\text { Consultant services } \\
\text { Fee: } \\
\text { 1. Mentoring (when } \\
\text { fulfilling AEO) } \\
\text { 2. AEO Internal Audit } \\
\text { (post AEO) }\end{array}$ & $\begin{array}{l}\text { 1. } 100.000 .000- \\
500.000 .000^{\star \star} \\
\text { 2. } 250.000 .000- \\
1.000 .000 .000 / \\
\text { year** }\end{array}$ & $\begin{array}{l}\text { 1. Only once } \\
\text { 2. Per year } \\
\text { (Routine) }\end{array}$ \\
\hline Training/Seminar fee & $\begin{array}{l}2.500 .000 / \\
\text { person }\end{array}$ & Only Once \\
\hline $\begin{array}{l}\text { Other costs related to } \\
\text { fulfillment of the AEO } \\
\text { requirements } \\
\text { (Infrastructure, HR, } \\
\text { Management, etc.) }\end{array}$ & $\begin{array}{l}1.000 .000 .000- \\
5.000 .000 .000^{\star \star *}\end{array}$ & Only Once \\
\hline $\begin{array}{l}\text { Notes: } \\
\text { *Depends on position, } \\
\text { ** Depends on the cont } \\
\text { *** Depends on the entr }\end{array}$ & $\begin{array}{l}\text { perience, educati } \\
\text { act agreement } \\
\text { epreneur }\end{array}$ & evel, etc. \\
\hline
\end{tabular}

Source: Research Interviewee, 2019

In implementing this policy, businesses must designate a manager who handles the AEO program and who is given exclusive authority over certain information access of economic operators. This is a mandatory AEO requirement. To fulfill this requirement, businesses must have minimum one individual or a special division that handles the AEO program. For this purpose, the author gives several options or alternatives which businesses can choose:

Table 5.6. Alternatives related to the AEO eligibility

\begin{tabular}{|l|l|}
\hline Alternative & Note \\
\hline Alternative 1 & $\begin{array}{l}\text { Looking for people who are customs } \\
\text { experts and making them employees. }\end{array}$ \\
\hline Alternative 2 & Using Customs Consultant Services. \\
\hline Alternative 3 & $\begin{array}{l}\text { Using existing employees to improve their } \\
\text { knowledge of customs by means of } \\
\text { training or seminars. }\end{array}$ \\
\hline Alternative 4 & $\begin{array}{l}\text { Using existing employees to improve their } \\
\text { knowledge of customs through self-study. }\end{array}$ \\
\hline
\end{tabular}

Source: Research Interviewee, 2019

In order to show the differences clearly among alternatives in the table 5.7, the author gives an example (with numbers) to establish a comparison of more efficient alternatives of increasing company costs, with the following conditions:

1. Alternative 1: Look for people who are customs experts and make them employees (2 employees) without consultants.

2. Alternative 2: Use Customs Consultant Services even after getting the AEO certification and the cost of fulfilling the AEO requirements.

3. Alternative 3: Using existing employees to improve their knowledge of Customs by means of training or seminars (for two employees).

4. Alternative 4: Use existing employees to increase their knowledge of Customs by self-study (2 employees) and the cost of fulfilling the AEO requirements.

To show the efficiency in terms of costs, the cost efficiency of each alternative is presented in the table 5.7: 
Table 5.7. Cost efficiency for each alternative (in millions of Rupiah)

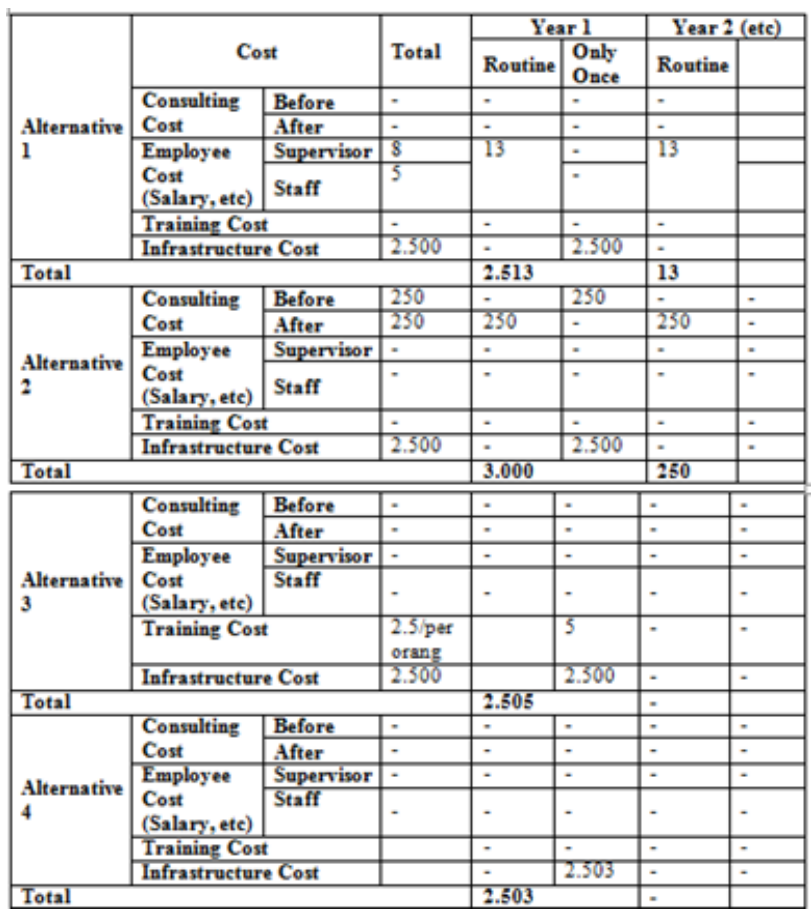

Source: Author's own data, 2019

As seen from the above table, in terms of cost efficiency, the fourth alternative (4) can be an option, because it only costs Rp. 2,503,000,000 for fulfilling the requirements and after obtaining the AEO certificate. In addition to employees' costs, training, consultants, and seminars, there are other costs, namely, the company's infrastructure costs. The costs borne for fulfilling the AEO requirements are quite high, besides the readiness of the businesses. The businesses must calculate the costs that must be incurred if they want to obtain the AEO certificate and compared them to the benefits they are granted.

\subsubsection{Time required for the implementation of AEO policy}

There is time needed to fulfill the AEO requirements and time to attend training or seminars related to Customs experts. The time for this AEO requirement can vary depending on the readiness of the businesses to apply the AEO policy (see table 5.8).
Table 5.8. Time for meeting the AEO requirements based on interviews

\begin{tabular}{|l|l|}
\hline Data source/Information & Fulfillment time \\
\hline DJBC (Head of $A E O$ Certification) & $2-6$ months \\
\hline Data source/Information & Fulfillment time \\
\hline Customs and Excise Consultant 1 & $6-12$ months \\
\hline Customs and Excise Consultant 2 & $8-12$ months \\
\hline PT. SGL & $6-8$ months \\
\hline PT. PLS & 6 months \\
\hline
\end{tabular}

Source: Author's own data, 2019

In addition, if a business participates in a training or expert customs seminar, it takes less time (see table 5.10).

Table 5.9. Time for AEO training and Customs experts

\begin{tabular}{|l|l|}
\hline Training & Training Time \\
\hline AEO (before and after) & $1-2$ days \\
\hline Customs Expert & 4 months \\
\hline \multicolumn{2}{|c|}{ Source: Author's own data, 2019 }
\end{tabular}

As explained in the previous section, businesses must appoint a manager who handles the AEO implementation and who is given exclusive authority over access to certain information on economic operators. To fulfill these requirements, businesses must have staff or a special division that handles the AEO program. If the company chooses alternative 3 , shown in the table 5.6, the company must carry out the AEO training or customs experts training.

\subsection{Analysis of the Implementation of $\mathrm{AEO}$ Policy}

\subsubsection{Authorized Economic Policy procedure stages or standards (AEO)}

In this policy, there are only two (2) agencies involved, namely DJBC, as a facilitator and a company as the applicant. In addition, this authorized economic policy does not prevent businesses from obtaining or submitting other facilitations. To facilitate the reader understanding, the author created the table 5.11 related to the categorization of businesses: 
Table 5.10. Type of Businesses

\begin{tabular}{|l|l|}
\hline Type & Businesses Type \\
\hline 1 & Exporter/Importer \\
\hline 2 & $\begin{array}{l}\text { Temporary stockpiling site (TPS), Bonded stockpiling } \\
\text { site (TPB), Transportation service }\end{array}$ \\
\hline 3 & PPJK Service \\
\hline 4 & Consolidators and others \\
\hline
\end{tabular}

Source: Author's own data, 2019

In fact, there were no problems related to these policy stages, but in following the stages of the process, the most difficult part for the businesses was when reviewing the requirements up to the fulfillment of repairs or guidance, due to the fact that compliance with requirements (13 requirements) is very difficult and quite expensive. These policy stages are in accordance with the SOPs that have been made. But when trying to fulfill these policy requirements businesses find them quite difficult and expensive, especially service businesses or types 2 and 3 businesses (according to the table 5.11). This resulted in a lack of interest in this policy, especially of service businesses, because the benefits granted were not worth the costs incurred.

Table 5.11. Adjustment of AEO certification terms with types of businesses

\begin{tabular}{|l|l|c|}
\hline \multicolumn{2}{|c|}{ Requirement } & Businesses type \\
\hline A & Shows customs compliance & $1,2,3,4$ \\
\hline B & Has a trade data management system & $1,2,3,4$ \\
\hline C & Has financial ability & $1,2,3,4$ \\
\hline D & $\begin{array}{l}\text { Has a system of consultation, } \\
\text { cooperation and communication }\end{array}$ & $1,2,3,4$ \\
\hline E & $\begin{array}{l}\text { Has a system of education, training and } \\
\text { care }\end{array}$ & $1,2,3,4$ \\
\hline F & $\begin{array}{l}\text { Has a system of information exchange, } \\
\text { access and confidentiality }\end{array}$ & $1,2,3,4$ \\
\hline G & Has a cargo security system & $1,2,4$ \\
\hline H & $\begin{array}{l}\text { Has a system of goods movement } \\
\text { security }\end{array}$ & $1,2,4$ \\
\hline I & Has a location security system & $1,2,3,4$ \\
\hline J & Has an employee security system & $1,2,3,4$ \\
\hline K & Has a trading partner security system & $1,2,4$ \\
\hline L & $\begin{array}{l}\text { Has a crisis management and incident } \\
\text { recovery system }\end{array}$ & $1,2,3,4$ \\
\hline M & $\begin{array}{l}\text { Has a system of planning and } \\
\text { implementing monitoring, } \\
\text { measurement, analysis, and system } \\
\text { improvement for all points }\end{array}$ & $1,2,3,4$ \\
\hline
\end{tabular}

Source: Author's own data, 2019

Judging from the thirteen points in the table 5.11, there is an adjustment, especially for type 3 businesses that are only related to PPJK Services. It is expected that adjusting the requirements would make fulfilling the requirements of the $\mathrm{AEO}$ program fairer.

\subsubsection{Differences in the benefits of the AEO program for businesses}

In the implementation of the AEOs policy, the benefits granted, especially for type 2 and 3 businesses, are not comparable with the costs incurred as opposed to type 1 businesses that are certain to obtain the optimal benefits of AEO policy. For this reason, the benefits that will be given to the businesses are adjusted to the type of business, following the table 5.13 regarding the adjustment of benefits to the type of business:

Table 5.12. Adjustment of the benefits of the AEO certification to the types of businesses

\begin{tabular}{|c|c|}
\hline Benefit & Businesses type \\
\hline Minimum document / physical check. & $1,2,3,4$ \\
\hline $\begin{array}{l}\text { Priority to get simplification of customs } \\
\text { procedures. }\end{array}$ & $1,2,3,4$ \\
\hline $\begin{array}{l}\text { Special services in the event of a disruption } \\
\text { to the movement of logistics supplies and } \\
\text { increasing } \\
\text { threats. }\end{array}$ & $1,2,3$ \\
\hline Pre-notification. & 1 \\
\hline Benefit & Businesses type \\
\hline $\begin{array}{l}\text { Can use corporate guarantees to } \\
\text { guarantee all activities in the customs } \\
\text { sector. }\end{array}$ & 1 \\
\hline $\begin{array}{l}\text { Ease of periodical payment for settlement } \\
\text { of customs obligations }\end{array}$ & 1 \\
\hline $\begin{array}{l}\text { Ease of dismantling and/or loading directly } \\
\text { from or to transporting facilities that come } \\
\text { from or will depart outside the customs } \\
\text { area to or from land } \\
\text { transportation facilities without landfill }\end{array}$ & 1 \\
\hline $\begin{array}{l}\text { Priority to be included in new programs } \\
\text { initiated by DJBC }\end{array}$ & $1,2,3,4$ \\
\hline $\begin{array}{l}\text { Get special services in the form of services } \\
\text { provided by the client manager }\end{array}$ & $1,2,3,4$ \\
\hline $\begin{array}{l}\text { Get customs settlement services outside } \\
\text { the Customs Office hours }\end{array}$ & $1,2,3,4$ \\
\hline
\end{tabular}

Source: Author's own data, 2019

As seen from the table 5.12, there are adjustments, especially for type 2, 3, and 4 businesses. Meanwhile, 
for type 1 businesses, it is certain to get all the benefits available.

\subsubsection{Technical obstacles to the implementation of AEO policy}

There are several obstacles posed by DJBC as the facilitator and implementer of this policy. These obstacles are related to HR issues, IT systems, and coordination among customs related agencies.

During the field research, the author found just a handful of people at DJBC who understood this policy. In managerial and bureaucratic terms, DJBC has a subdirectorate specifically handling the AEO certification under the Customs Technical Directorate, namely, the AEO Sub-directorate and Priority Program. In the AEO certification section, there are only seven employees responsible for validating the $\mathrm{AEO}$ request. If there are still a lot of implementers who do not understand this policy, then this policy does not work well. The solution would be to arrange a special short seminar about the AEO program, at the Customs and Excise Public Service Office (KPU BC), especially the KPU BC, which has the AEO businesses like KPU BC Tanjung Priok.

The following issue is the existence of technical problems in IT. The implementation of this policy has actually been supported by the Indonesia National Single Window system. Through this system, DJBC, administratively acting as the facilitator, receives documents related to the expenditure of goods, facilitations used, tariffs, and other facilitations as the basis for SPPB expenditure. While conducting the field research, the author found that IT system problems could lead to DJBC slow service.

In addition, the lack of coordination between agencies related to Customs hampers the process of implementing this AEO policy. In its implementation in practice, this AEO policy does not prevent businesses from obtaining other Customs facilitations, for example exemption from customs import duty. Even though they already have the AEO certification, businesses can still apply for exemption from customs import duty. While doing a field research, the author was informed that obtaining this $\mathrm{COO}$ took long time, so that it could hamper customs administration. In addition, the lack of coordination between institutions in the process of exemption from customs import duty has resulted in the customs administration being slow and longer loading and unloading times.

\section{CONCLUSION}

There are several strengths and weaknesses to consider. The AEOs policy has many advantages, e.g. the acceleration of customs administration, ease in loading and unloading, security in customs procedures, as well as priority programs / special services and other benefits.

In contrast, the AEOs policy also have weaknesses, namely, the relative cost and time needed for implementation of the AEO policy. These weaknesses can be used as a reference to businesses not having the AEO certification to decide whether to participate in this AEO policy or not. In addition, the government can use it as the input information in evaluating this policy.

However, there are several problems in implementing the AEO policy and encouraging the acceleration of customs administration. At the stage of fulfilling the requirements, businesses perceive these requirements very difficult and expensive to fulfill. Therefore, in terms of the benefits to the businesses, particularly type 2 businesses (TPS, TPB, freight forwarders) and type 3 businesses (PPJK Services) can get benefits that are comparable to the costs already incurred. In addition, DJBC has neither sufficient human resources, nor properly operating IT system for the implementation of the AEO policy. This causes a disruption in the AEO policy implementation, especially in the Customs procedures.

\section{REFERENCES}

[1] Bea Cukai. 2015.2 "AEO" <http://www.beacukai.go.id/arsip/pab/aeo.html>.

[2] Bea Cukai. 2015. "AEO". < http://www.beacukai.go.id/arsip/pab/aeo.html>

[3] Erceg, Aleksandar. (2014). Influence of Authorized Economic Operators On Supply Chain Security. Volume 14, pp 93-101. 14th International Scientific Conference. Osijek, Croatia.

[4] Neuman, W. (2006). Basics of Social Research Method: Qualitative and Quantitative Approach. Boston: Pearson Education Inc.

[5] Pressman, Jeffery. L., \& Wildavasky, Aaron. (1973). Implementation: How Great Expectation In Washington are dashed in Oakland.Berkley. University California Press

[6] Rosdiana, Haula \& Tarigan, Rasin. (2005). Perpajakan Teori dan Aplikasi. Jakarta: Rajagrafindo Persada.

[7] Rosdiana, Haula., Slamet, Irianto. (2012). Pengantar Ilmu Pajak. Jakarta: Raja Grafindo Persa

[8] Winarno, Budi. (2002). Teori dan Proses KebijakanPublik. Yogyakarta: Elex Media Pressindo 